\title{
The adaptive response of bone to mechanical loading in female transgenic mice is deficient in the absence of oestrogen receptor- $\alpha$ and $-\beta$
}

\author{
K C L Lee, H Jessop, R Suswillo, G Zaman and L E Lanyon \\ Department of Veterinary Basic Sciences, The Royal Veterinary College, Royal College Street, London NW1 OTU, UK \\ (Requests for offprints should be addressed to L E Lanyon; Email: llanyon@rvc.ac.uk)
}

\begin{abstract}
Postmenopausal osteoporosis represents a failure of the response by which bone cells adapt bone mass and architecture to be sufficiently strong to withstand loading without fracture. To address why this failure should be associated with oestrogen withdrawal, we investigated the ulna's adaptive response to mechanical loading in adult female mice lacking oestrogen receptor- $\alpha\left(E R \alpha^{-\prime-}\right)$, those lacking oestrogen receptor- $\beta\left(\operatorname{ER} \beta^{-I^{-}}\right)$and their wild-type littermates. In wild-type mice, short periods of physiologic cyclic compressive loading of the ulna in vivo over a 2-week period stimulates new bone formation. In $\mathrm{ER} \alpha^{-/-}$and $\mathrm{ER} \beta^{-/-}$mice this osteogenic response was respectively threefold and twofold less $(P<0 \cdot 05)$. In vitro, primary cultures of osteoblast-like cells derived from these mice were subjected to a single short period of mechanical strain. Twenty-four hours after strain the number of wild-type cells was $61 \pm 25 \%$ higher than in unstrained
\end{abstract}

controls $(P<0 \cdot 05)$, whereas in $\mathrm{ER} \alpha^{-\prime-}$ cells there was no strain-related increase in cell number. However, the strain-related response of $\mathrm{ER} \alpha^{-/-}$cells could be partially rescued by transfection with functional human ER $\alpha$ $(P<0 \cdot 05) . \mathrm{ER} \beta^{-\prime-}$ cells showed a $125 \pm 40 \%$ increase in cell number following strain. This was significantly greater than in wild types $(P<0 \cdot 05)$.

These data support previous findings that functional $\mathrm{ER} \alpha$ is required for the full osteogenic response to mechanical loading and particularly the stage of this response, which involves an increase in osteoblast number. ER $\beta$ appears to depress the ER $\alpha$-mediated strain-related increase in osteoblast number in vitro, but in female transgenic mice in vivo the constitutive absence of either $\mathrm{ER} \alpha$ or $\mathrm{ER} \beta$ appears to diminish the osteogenic response to loading.

Journal of Endocrinology (2004) 182, 193-201

\section{Introduction}

Postmenopausal osteoporosis represents a failure of the normal homeostatic mechanisms by which functional load bearing establishes and maintains a sufficiently robust bone structure to withstand the forces of everyday activities without fracture (Lanyon \& Skerry 2001). We hypothesise that this failure is due to a reduction in oestrogen receptor (ER) number and/or function in bone cells resulting from oestrogen deficiency.

It is currently believed that most of the functions of oestrogen in bone are mediated by ER $\alpha$ (Riggs et al. 2002). These include the regulation of osteoblast proliferation and differentiation, the synthesis of bone matrix proteins, the promotion of osteocyte survival, the suppression of bone resorption and the promotion of osteoclast apoptosis (Riggs et al. 2002). In vitro evidence suggests that $\mathrm{ER} \alpha$ in bone cells is also involved in mediating responses to mechanical stimulation. The strain-related increase in cell number of monolayer cultures of rat and human osteoblast-like cells can be blocked with ER antagonists and enhanced by transfection with additional ER $\alpha$ (Damien et al. 1998, 2000, Zaman et al. 2000, Cheng et al. 2002). Moreover, mechanical strain stimulates ER $\alpha$ phosphorylation and oestrogen response element (ERE) activation via a pathway which is dependent on three well-established mediators of the in vivo osteogenic response of whole bones to mechanical loading: movement of calcium ions and the production of nitric oxide and prostaglandins (Zaman et al. 2000, Jessop et al. 2001, 2002).

Support for a reduction in ER number and function in bone cells in oestrogen-deficient states has been published by other workers. Bone biopsies from oestrogen-deficient women have fewer ER $\alpha$-positive osteocytes than those from oestrogen-replete women (Hoyland et al. 1999) and osteoblasts cultured from postmenopausal women are less responsive to oestrogen compared with osteoblasts from younger women in terms of oestrogen-induced collagen synthesis and ERE activation (Ankrom et al. 1998). In addition, reduced levels of ER $\alpha$ mRNA have been detected in trabecular bone following ovariectomy in rats (Lim et al. 1999). 
The inference that adaptive bone (re)modelling would be dependent upon functional ER $\alpha$ was supported by data from a pilot experiment in vivo (Lee et al. 2003), which showed that the loading response of ER $\alpha$ knockout $\left(\mathrm{ER} \alpha^{-/-}\right)$mice was threefold less than that in wild-type littermates. However, unravelling the effects of ER in bone cells is complicated by the presence of two ERs: $\mathrm{ER} \alpha$ and ER $\beta$. Both are present in osteoblasts but the action of $E R \beta$ in particular is currently uncertain (Riggs et al. 2002). Studies of ER $\beta$ knockout $\left(\operatorname{ER} \beta^{-l^{-}}\right)$mice suggest that ER $\beta$ is not required for the protective effect of oestrogen on bone mass. The responses of the bones of young adult $\operatorname{ER} \beta$ knockout $\left(\operatorname{ER} \beta^{-/-}\right)$female mice to ovariectomy and oestrogen-replacement therapy have been shown to be the same as those in wild types (Sims et al. 2002). However, 1-year-old female ER $\beta^{-/-}$mice have a low bone turnover and a high bone mineral density compared with wild types. This phenotype has been associated with higher ER $\alpha \mathrm{mRNA}$ levels in the bones of $\mathrm{ER} \beta^{-/-}$mice compared with wild types (Windahl et al. 2001). Therefore ER $\beta$ may have a repressive effect on $\mathrm{ER} \alpha$ expression in bone and thus an inhibitory effect on the maintenance of an appropriate bone mass by oestrogen and mechanical loading.

The primary aim of the study reported here was to investigate the role of both $\operatorname{ER} \alpha$ and $\operatorname{ER} \beta$ in bone's adaptive response to mechanical loading. In vivo we did this by studying the osteogenic response of the ulna of $\mathrm{ER} \alpha^{-/-}, \mathrm{ER} \beta^{-1-}$ and wild-type mice to mechanical loading. We then cultured ER $\alpha^{-/-}, \operatorname{ER} \beta^{-1-}$ and wild-type osteoblast-like cells from these mice and assessed in vitro changes in cell number following a period of mechanical strain. In addition, we assessed the effect of transfection of human ER $\alpha$ on the strain responsiveness of ER $\alpha^{-/-}$cells.

\section{Materials and Methods}

\section{Mice}

$\mathrm{ER} \alpha$ knockout $\left(\mathrm{ER} \alpha^{-/-}\right)$and $\operatorname{ER} \beta$ knockout $\left(\mathrm{ER} \beta^{-\prime^{-}}\right)$mice were bred from two distinct breeding colonies. ER $\alpha^{-/-}$mice were homozygous for an insertional mutation in the first coding exon, exon 2, of the mouse ER $\alpha$ gene (Lubahn et al. 1993). ER $\beta^{-/-}$mice were homozygous for an insertional mutation in exon 3 of the mouse ER $\beta$ gene (Krege et al. 1998). The background strain of both colonies was C57Bl/6J. Knockout and wild-type littermates were bred from heterozygous breeding pairs. Hereafter $\mathrm{ER} \alpha^{+/+}$and $\mathrm{ER} \beta^{+/+}$mice represent the wild-type littermates of $\mathrm{ER} \alpha^{-/-}$and $\operatorname{ER} \beta^{-/-}$ mice respectively.

Mice were genotyped by PCR analysis. Primers used for detection of the intact and disrupted ER $\alpha$ genes were 5'-AACTCGCCGGCTGCCACTTACCAT-3' (ER $\alpha$ exon 2), 5'-CATCAGCGGGCTAGGCGACACG-3'

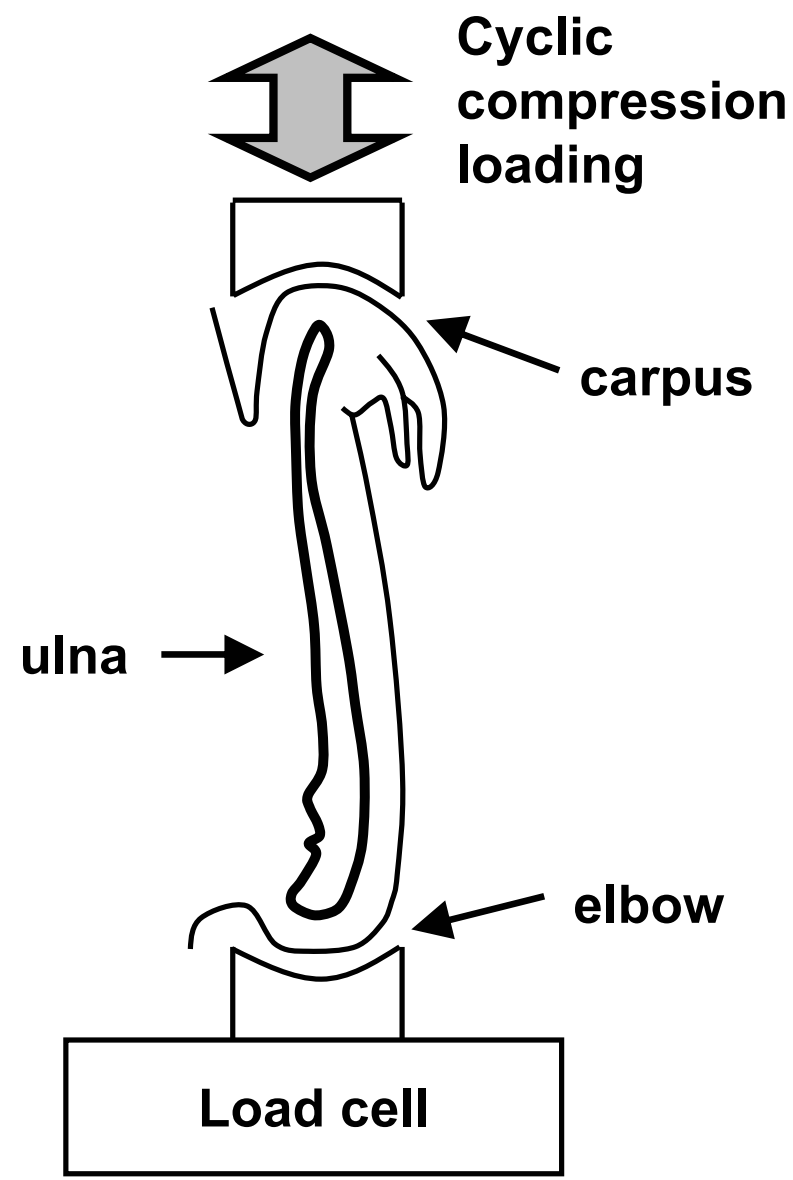

Figure 1 Diagram of the mouse ulna loading apparatus.

(ER $\alpha$ exon 2) (Vidal et al. 2000), 5'-GTGTTCCGG CTGTCAGCGCA-3' (neomycin cassette) and 5'-GTC CTGATAGCGGTCCGCCA-3' (neomycin cassette) (K S Korach, personal communication). Primers used for detection of the intact and disrupted $\operatorname{ER} \beta$ genes were 5'-AGAATGTTGCACTGCCCCTGCTGC-3' (ER $\beta$ intron 2), 5'-GGAGTAGAAACAAGCAATCCAGAC ATC-3' (ER $\beta$ intron 3) and 5'-GCAGCCTCTGTT CCACATACACTTC-3' (neomycin cassette) (Windahl et al. 1999).

Breeding colonies were maintained under standardized conditions, in a specific pathogen-free environment, with free access to water and a standard breeding or maintenance rodent diet as appropriate. All animal procedures complied with the Animals (Scientific Procedures) Act 1986 and institutional guidelines.

\section{Calibration of the in vivo mechanical loading apparatus}

The technique for applying cyclic axial compression to the mouse ulna in vivo through the flexed elbow and flexed carpus has been published previously (Fig. 1) (Lee et al. 2002). 
The forces required to produce the peak strains and strain rates previously recorded from the ulna during locomotion (Lee et al. 2002) were determined ex vivo, using four forelimbs from 20- to 24-week-old female mice from each of the following four groups: ER $\alpha^{-1-}$ mice and their $\mathrm{ER} \alpha^{+/+}$littermates; $\mathrm{ER} \beta^{-i-}$ mice and their $\mathrm{ER} \beta^{+/+}$ littermates. Strain gauges (EA-06-015 LA-120; Measurements Group UK Ltd, Basingstoke, Hamps, UK) were bonded to the lateral midshaft of each ulna and the forelimb positioned in the loading apparatus as shown in Fig. 1. The relationship between force and strain under axial compression loading was determined using linear regression analysis and slopes and intercepts were compared between genotypes using the Mann-Whitney test.

\section{In vivo loading}

The left ulnae of eight 20- to 24-week-old female $\mathrm{ER} \alpha^{-/-}$mice and seven of their $\mathrm{ER} \alpha^{+/+}$littermates were loaded by cyclic axial compression for $10 \mathrm{~min}$ on 3 alternate days each week for 2 weeks. In a separate experiment, the left ulnae of four 20- to 24-week-old female ER $\beta^{-1-}$ mice and four of their ER $\beta^{+/+}$littermates were loaded using the same regimen. The right ulnae of these mice served as non-loaded paired controls. Loading sessions comprised 40 cycles of a trapezoidal waveform with a peak load of $-3 \cdot 4$ Newtons $(\mathrm{N})$, which engendered peak strains of 2800 microstrain at a maximum strain rate of $0 \cdot 1 / \mathrm{s}$ at the lateral ulna midshaft. Following each load cycle there was a rest period of $14.9 \mathrm{~s}$ (Srinivasan et al. 2002).

Mice were anaesthetised for loading by intraperitoneal injection with a mixture of fentanyl citrate, fluanisone and sterile water and received $0.15 \mathrm{ml} 0.9 \%$ sterile saline subcutaneously as routine anaesthetic fluid replacement therapy. Mice carried out normal activities between loading periods without signs of lameness. On day 15, blood samples were obtained from each mouse by intracardiac puncture under terminal inhalation halothane anaesthesia. Mice were killed by cervical dislocation.

\section{Assessment of the in vivo adaptive response to mechanical loading}

The ulna's response to loading was assessed histomorphometrically with the aid of double calcein labels (Sigma, Poole, Dorset, UK) administered at $7.5 \mathrm{mg} / \mathrm{kg}$ on days 3 and 12. Ulnae were harvested, cut transversely at the midshaft, fixed in neutral buffered formalin and embedded in methylmethacrylate as previously described (Mosley et al. 1997). Serial transverse sections were cut from the midshaft at $500 \mu \mathrm{m}$ intervals, using a diamond sintered annular saw (Microslice II; Cambridge Instruments, Malvern, Worcs, UK). Computer images of the surface of each section were generated using the $488 \mathrm{~nm}$ argon laser and Plan-Neofluar $10 \times$ objective lens (numerical aperture 0.3) of a laser scanning confocal microscope (Carl Zeiss Ltd, Welwyn Garden City, Herts, UK). Each pixel in these images measured $0.86 \mu \mathrm{m} \times 0.86 \mu \mathrm{m}$. Sections $3.5 \mathrm{~mm}$ distal to the midshaft were analysed in detail. This site lay within the region which showed the maximum loading response in previous experiments using adult CD1 mice (Lee et al. 2002). Quantitative histomorphometry was performed using the KS300 software (Imaging Associates Ltd, Thame, Oxon, UK), according to the recommendations of the American Society for Bone and Mineral Research (Parfitt et al. 1987) and as detailed previously (Lee et al. 2002).

Statistical differences between paired control and loaded ulnae for each genotype were determined using the paired $t$-test. ER $\alpha^{-}$and $\operatorname{ER} \beta^{-\prime-}$ ulnae were compared with their wild-type counterparts using the non-paired $t$-test. To control for differences between control ER $\alpha^{+/+}$ and control ER $\alpha^{-/-}$ulnae and between control ER $\beta^{+/+}$ and control ER $\beta^{-/-}$ulnae, 'loading-induced' values for each parameter were calculated by subtracting the value for each control ulna from that of its paired loaded ulna. Loading-induced values were compared between knockouts and their wild-type littermates using the non-paired $t$-test.

\section{Primary osteoblast cultures}

Osteoblast-like cells were isolated from cortical explants of the long bones of 6- to 10-week-old, male and female, $\mathrm{ER} \alpha^{-{ }^{-}}, \mathrm{ER} \beta^{-\prime^{-}}$and wild-type mice using the cell outgrowth method as previously described (Jessop et al. 2002). All tissue culture reagents were obtained from Invitrogen unless otherwise stated. Briefly, all the soft tissues were removed from the long bones and their marrow cavities were flushed with phosphate-buffered saline (PBS). Long bones were then cut into small fragments and cultured in Dulbecco's modified Eagle's medium (DMEM) containing 10\% heat inactivated fetal calf serum (FCS) supplemented with $2 \mathrm{mM} \mathrm{L}$-glutamine, $100 \mathrm{U} / \mathrm{ml}$ penicillin and $100 \mu \mathrm{g} / \mathrm{ml}$ streptomycin. Bone fragments were incubated in $5 \% \mathrm{CO}_{2}$ at $37{ }^{\circ} \mathrm{C}$ for 21 days to achieve approximately $70 \%$ cell confluency. Media were replenished weekly.

On day 21, cells were washed in PBS and released with $0.05 \%$ trypsin and $0.02 \%$ EDTA for subculture. Only first passage cells were used for the following experiments. Sample cells were reserved at each extraction to confirm an osteoblastic phenotype. These cells expressed alkaline phosphatase, synthesised osteocalcin and formed mineralised nodules in long-term culture in the presence of $50 \mu \mathrm{g} / \mathrm{ml}$ ascorbic acid and $10 \mathrm{mM} \beta$-glycerophosphate (Sigma) (Zaman et al. 1997).

\section{Transfection and mechanical straining of osteoblast cultures}

Four sets of primary osteoblast-like cell cultures were prepared for mechanical straining: $\mathrm{ER} \alpha^{-/-}$cells, 
ER $\beta^{-/-}$cells, wild-type cells and ER $\alpha^{-/-}$cells transfected with a functional human wild-type ER $\alpha$ expression vector, pRST7-ER (Tzukerman et al. 1994). All cells were seeded in monolayers onto sterile, tissue culturetreated, plastic strips (Nunc, Dossel, Germany) at a density of 80000 cells per strip and incubated in DMEM containing 10\% charcoal dextran-stripped FCS. The only exception was the ER $\alpha^{-/-}$cells for transfection, which were seeded at a density of 50000 cells per strip.

$\mathrm{ER} \alpha^{-1-}$ cells were transiently transfected with pRST7-ER using Effectene (Qiagen) according to the manufacturer's instructions. One $\mu \mathrm{g}$ pRST7-ER vector was used per strip and the incubation period was $3 \mathrm{~h}$. To determine transfection efficiency, cells were simultaneously transfected with a lac $z$ expression plasmid, at a concentration of $1 \mu \mathrm{g}$ DNA per strip. $\beta$-Galactosidase activity was detected in fixed cells by histochemical staining (lac $z$ staining kit; Promega) and the percentage of positive cells was calculated using phase contrast microscopy at a magnification of $\times 200$.

Monolayer cell cultures were cyclically loaded by fourpoint bending for $10 \mathrm{~min}$ at a frequency of $1 \mathrm{~Hz}$ to peak strains of 3400 microstrain, using a custom designed loading apparatus as described previously (Zaman et al. 1997). Following loading, cultures were retained in the same culture medium and incubated for a further $24 \mathrm{~h}$. The cells were then washed in PBS, fixed for $15 \mathrm{~min}$ in neutral-buffered formalin (BDH, Poole, Dorset, UK), washed twice in PBS and stored at $4{ }^{\circ} \mathrm{C}$ pending analysis. Control cultures were treated in the same way as strained cultures including being subjected to the same fluid perturbations, except they were not exposed to cyclic mechanical strain. Each experiment consisted of three strained and three control strips. Experiments were repeated three to five times.

\section{Assessment of the proliferative response of osteoblasts to mechanical strain}

The in vitro response of osteoblasts to mechanical strain was measured in terms of cell proliferation, by comparing the numbers of cells in strained cultures to those in nonstrained control cultures by manual cell counting. To facilitate cell counting the nuclei of the fixed cells were stained with a fluorochrome, Hoechst 33258 (Sigma), using a modification of a previously described method (Rago et al. 1990). Briefly, fixed cells were washed with distilled water and incubated in $1 \mathrm{mg} / \mathrm{ml}$ Hoechst 33258 in TNE buffer $(10 \mathrm{mM}$ Tris, $1 \mathrm{mM}$ EDTA and $2 \mathrm{M}$ $\mathrm{NaCl}, \mathrm{pH} 7 \cdot 4)$ in the dark for $30 \mathrm{~min}$. Cells were then blotted dry and mounted in glycerol. Cells were counted in 16 randomly chosen frames per strip using an ultraviolet microscope at $\times 4$ magnification and the KS300 image analysis software (Imaging Associates Ltd). The mean number of cells per frame per strip was calculated. Cell number on strained and non-strained controls were

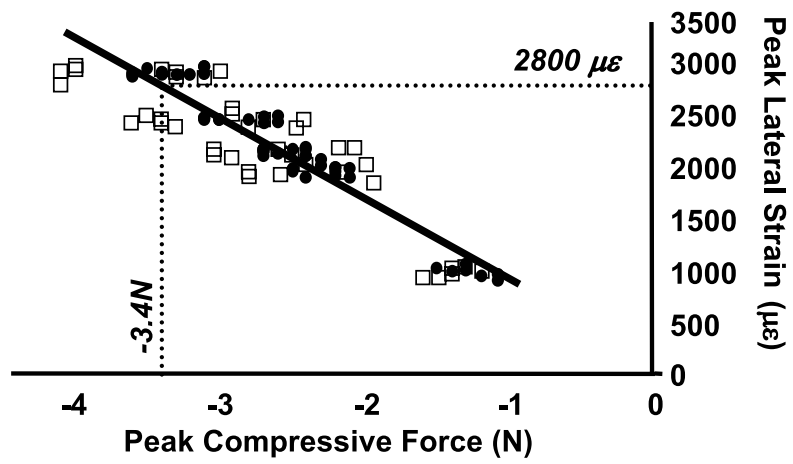

Figure 2 A scatter plot demonstrating the linear relationship between force and peak tension strain at the lateral ulna midshaft during cyclic axial compression loading ex vivo for $\mathrm{ER \alpha}^{+/+}(\square)$ and $\mathrm{ER} \alpha^{-/-}(\mathbf{O})$ ulnae. This relationship was not significantly different between $\mathrm{ER \alpha}^{+/+}$and $\mathrm{ERa}^{-/-}$ulnae. Ulnae were loaded in vivo using a peak compressive force of $-3 \cdot 4 \mathrm{~N}$. (The corresponding scatter plot for $E R \beta^{+/+}$and $E R \beta^{-/-}$ulnae was very similar and is therefore not shown.) $\mu \varepsilon$, microstrain.

compared using the paired $t$-test. Responses to mechanical strain were then expressed as the percentage difference in cell number between strained cultures and non-strained controls.

All statistical tests were carried out using SPSS10 (SPSS Inc., Chicago, IL, USA) and a 5\% significance level. Data are presented as means \pm S.E. unless otherwise stated.

\section{Results}

Absence of ERa or ER $\beta$ has no effect on stiffness under axial compression

ER $\alpha^{-/-}$ulnae $(13.2 \pm 0.02 \mathrm{~mm}, n=4)$ were $4 \%$ shorter

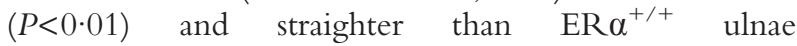
$(13.8 \pm 0.01 \mathrm{~mm}, n=4)$. The length (and shape) of $E R \beta^{-/-}$ulnae $(13.6 \pm 0.17 \mathrm{~mm}, n=4)$ was not significantly different from $E R \beta^{+/+}$ulnae $(13.7 \pm 0.03 \mathrm{~mm}$, $n=4)$. Ex vivo, cyclic axial compression loading of each of these ulnae revealed a strong linear correlation $\left(\mathrm{R}^{2}>0 \cdot 96\right.$, $P<0 \cdot 001)$ between peak compressive force and peak tension strain at the lateral ulna surface between $1 \cdot 0 \mathrm{~N}$ and $4 \cdot 0 \mathrm{~N}$. No significant differences in the structural stiffness of the mouse ulna under cyclic axial compression loading were found between $\mathrm{ER} \alpha^{-/-}$and $\mathrm{ER} \alpha^{+/+}$mice and between $\operatorname{ER} \beta^{-/-}$and $\operatorname{ER} \beta^{+/+}$mice. Therefore data from knockout mice and their wild-type littermates were collated to predict the strain engendered at the lateral ulna midshaft under axial compression loading (Fig. 2). For $\mathrm{ER} \alpha^{-1-}$ and $\mathrm{ER} \alpha^{+/+}$ulnae: peak lateral strain $=(-804.88 \times$ peak compressive force $)+104.56$; $\mathrm{R}^{2}=0.86 ; P<0 \cdot 001$. For $\mathrm{ER} \beta^{-/-}$and $\mathrm{ER} \beta^{+/+}$ulnae: peak lateral strain $=(-730 \cdot 25 \times$ peak compressive force $+365 \cdot 21 ; \mathrm{R}^{2}=0 \cdot 69 ; P<0 \cdot 001$. Therefore for both 
Table 1 Ulna cortical areas and perimeters

\begin{tabular}{|c|c|c|c|c|}
\hline & $\mathbf{E} \boldsymbol{R} \boldsymbol{\alpha}^{+/+}(n=7)$ & $\mathbf{E} \boldsymbol{R} \boldsymbol{\alpha}^{-1-}(n=8)$ & $\mathbf{E R}^{+/+}(n=4)$ & $\operatorname{ER}^{-1-}(n=4)$ \\
\hline $\begin{array}{l}\text { Cortical bone area } \\
\left(\mathrm{mm}^{2}\right)\end{array}$ & $\begin{array}{r}0 \cdot 206 \pm 0 \cdot 005 \\
P=C\end{array}$ & $\begin{array}{l}0 \cdot 231 \pm 0 \cdot 007 \\
021\end{array}$ & & n.s. \\
\hline $\begin{array}{c}\text { Marrow cavity } \\
\text { area }\left(\mathrm{mm}^{2}\right)\end{array}$ & $0.024 \pm 0.003$ & $0 \cdot 022 \pm 0 \cdot 002$ & $0 \cdot 017 \pm 0 \cdot 003$ & $0.022 \pm 0.005$ \\
\hline $\begin{array}{l}\text { Periosteal } \\
\quad \text { perimeter }(\mathrm{mm})\end{array}$ & $\begin{array}{r}1 \cdot 884 \pm 0 \cdot 032 \\
P=0\end{array}$ & $\begin{array}{l}1 \cdot 987 \pm 0 \cdot 032 \\
042\end{array}$ & $1 \cdot 882 \pm 0.028$ & $1 \cdot 812 \pm 0 \cdot 044$ \\
\hline $\begin{array}{l}\text { Endosteal } \\
\text { perimeter (mm) }\end{array}$ & $0.615 \pm 0.034$ & $0 \cdot 598 \pm 0 \cdot 021$ & $0 \cdot 529 \pm 0.053$ & $0.587 \pm 0.063$ \\
\hline
\end{tabular}

Cortical areas and perimeters were measured $3.5 \mathrm{~mm}$ distal to the ulna midshaft in the non-loaded control ulnae.

$P$ values represent comparisons between knockouts $\left(E R \alpha^{-/-}\right.$and $E R \beta^{-/-}$) and their wild-type littermates $\left(E R \alpha^{+/+}\right.$and $\left.E R \beta^{+/+}\right)$. n.s., $P>0 \cdot 05$.

knockouts and their wild-type littermates a peak compressive force of $-3 \cdot 4 \mathrm{~N}$ resulted in a peak lateral strain of 2800 microstrain.

Histomorphometric comparisons between non-loaded control knockout and wild-type ulnae

Histomorphometric analysis of the non-loaded control ulnae for the in vivo loading experiment demonstrated small but significant differences between the baseline adult skeletal phenotype of $\mathrm{ER} \alpha^{-/-}$and $\mathrm{ER} \alpha^{+/+}$mice. There were no significant differences between the baseline adult skeletal phenotype of $E R \beta^{-/-}$and $E R \beta^{+/+}$mice.

Non-loaded control ER $\alpha^{-/-}$ulnae had a $12 \%$ greater cortical area and a $6 \%$ greater periosteal perimeter than non-loaded control $\mathrm{ER}^{+/+}$ulnae, but there were no significant differences in marrow cavity area or endosteal perimeter between genotypes (Table 1). Periosteal modelling activity was barely detectable in all non-loaded control ulnae, as expected for adult mice with a mature skeleton (Sheng et al. 1999) (Fig. 3). Likewise, endosteal bone turnover was consistent with skeletal maturity in all non-loaded control ulnae, but endosteal mineralising surface and bone formation rate were significantly lower in $\mathrm{ER} \alpha^{-1-}$ ulnae compared with $\mathrm{ER} \alpha^{+/+}$ulnae $(P<0 \cdot 050)$ (Fig. 4).

The osteogenic adaptive response to mechanical loading is threefold lower in $\mathrm{ERa^{-/- }}$ mice compared with $\mathrm{ERa}^{+/+}$ mice

Short periods of mechanical loading to peak strains of 2800 microstrain on 3 alternate days each week for 2 weeks stimulated periosteal and endosteal bone formation in the ulnae of both adult female $\mathrm{ER} \alpha^{-/-}$and $\mathrm{ER} \alpha^{+/+}$mice. In $\mathrm{ER} \alpha^{+/+}$ulnae this resulted in an $8 \pm 0 \cdot 8 \%(P<0 \cdot 001)$ increase in cortical area. However, in ER $\alpha^{-1-}$ ulnae the loading-induced increase in cortical area was threefold less $(P<0.001)$ than in $\mathrm{ER} \alpha^{+/+}$ulnae resulting in only a $2 \cdot 4 \pm 0 \cdot 8 \%(P<0 \cdot 001)$ increase in cortical area (Fig. 5).
In both $\mathrm{ER}^{+/+}$and $\mathrm{ER} \alpha^{-/-}$ulnae, $80 \%$ of the loading-induced increase in cortical area was due to periosteal expansion and the remainder was due to endosteal new bone formation (Table 2). Both loading-induced periosteal and endosteal bone formation rates were $60 \%$ lower in $\mathrm{ER} \alpha^{-/-}$ulnae compared with $\mathrm{ER} \alpha^{+/+}$ulnae $(P=0.001)$ (Figs 3 and 4$)$. At the periosteum this was due to a $40 \%$ lower loading-induced increase in periosteal mineralising surface in $\mathrm{ER} \alpha^{-/-}$ulnae compared with
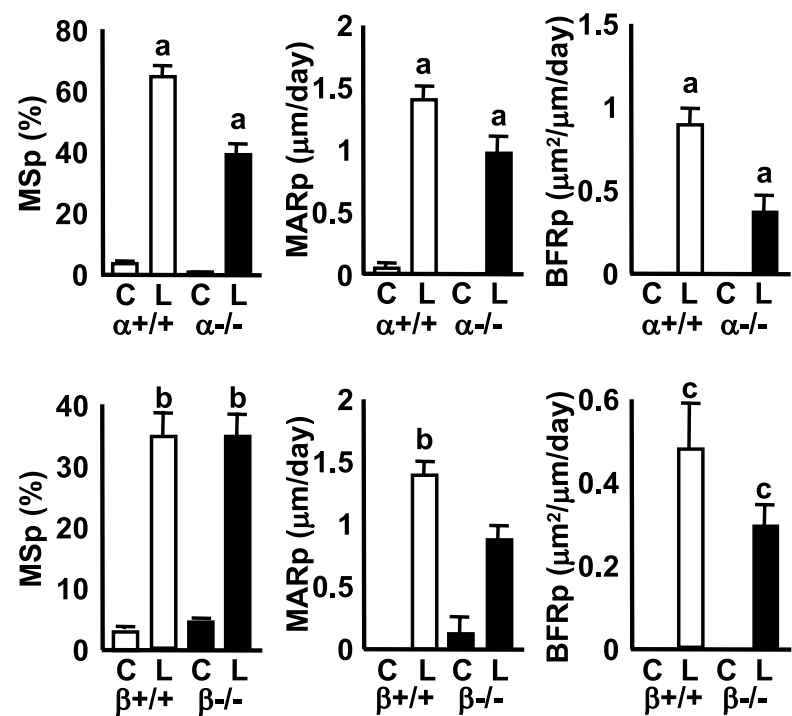

Figure 3 Histomorphometric analysis of the periosteal osteogenic response to mechanical loading in $\mathrm{ER}^{+/+}(\alpha+/+), \mathrm{ER} \alpha^{-}$ $(\alpha-/-), \operatorname{ER}^{+/+}(\beta+/+)$ and ER $\beta^{-/-}(\beta-/-)$ ulnae. Periosteal mineralising surface (MSp), periosteal mineral apposition rate (MARp) and periosteal bone formation rate (BFRp) in loaded (L) and control (C) ulnae. a, $P<0.001 ; b, P<0.010 ; c, P<0.050$ for comparisons between control and loaded ulnae of the same genotype. Values are means \pm S.E. 

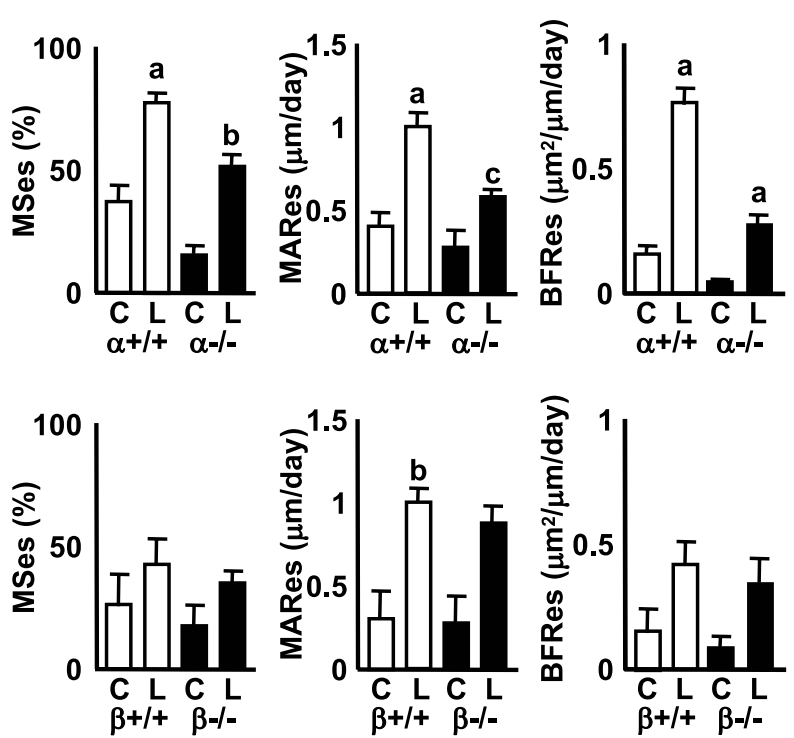

stimulated periosteal (but not endosteal) bone formation in the ulnae of both adult female $\operatorname{ER} \beta^{-/-}$and $\operatorname{ER} \beta^{+/+}$ mice. In $E R \beta^{+/+}$ulnae, this resulted in a $6 \pm 1.0 \%$ $(P=0.007)$ increase in cortical area. However, in $\operatorname{ER} \beta^{-1-}$ ulnae, the loading-induced increase in cortical area was twofold less $(P=0 \cdot 035)$ than in $\mathrm{ER} \beta^{+/+}$ulnae resulting in only a $3 \cdot 1 \pm 0 \cdot 7 \%(P=0 \cdot 017)$ increase in cortical area (Fig. 5). This was associated with a 50\% lower loading-induced increase in periosteal mineral apposition rate in $\operatorname{ER} \beta^{-/-}$ulnae compared with $\mathrm{ER} \beta^{+/+}$ulnae $(P=0 \cdot 049$, Table 2$)$.

There was no evidence of gross fractures, microfractures, bone resorption or intracortical remodelling in any of the loaded ulnae. The loading-induced osteogenic responses were therefore representative of physiological adaptation to an altered mechanical environment as demonstrated previously using the CD1 mouse (Lee et al. 2002).

Figure 4 Histomorphometric analysis of the endosteal osteogenic response to mechanical loading in $E R \alpha^{+/+}(\alpha+/+), E R \alpha$ $(\alpha-/-), E R \beta^{+/+}(\beta+/+)$ and $\left.\operatorname{ER} \beta^{-/-}(\beta-/-)\right)$ ulnae. Endosteal mineralising surface (MSes), endosteal mineral apposition rate (MARes) and endosteal bone formation rate (BFRes) in loaded ( $\mathrm{L}$ ) and control (C) ulnae. a, $P<0.001 ; b, P<0.010 ; c, P<0.050$ for comparisons between control and loaded ulnae of the same genotype. Values are means \pm S.E.

$\mathrm{ER} \alpha^{+/+}$ulnae $(P=0 \cdot 001)$ and at the endosteum this was due to a $50 \%$ lower loading-induced increase in endosteal mineral apposition rate $(P=0 \cdot 023)$.

The osteogenic adaptive response to mechanical loading is twofold lower in $E R \beta^{-1-}$ mice compared with $E R \beta^{+/+}$mice

Short periods of mechanical loading to peak strains of 2800 microstrain on 3 alternate days each week for 2 weeks

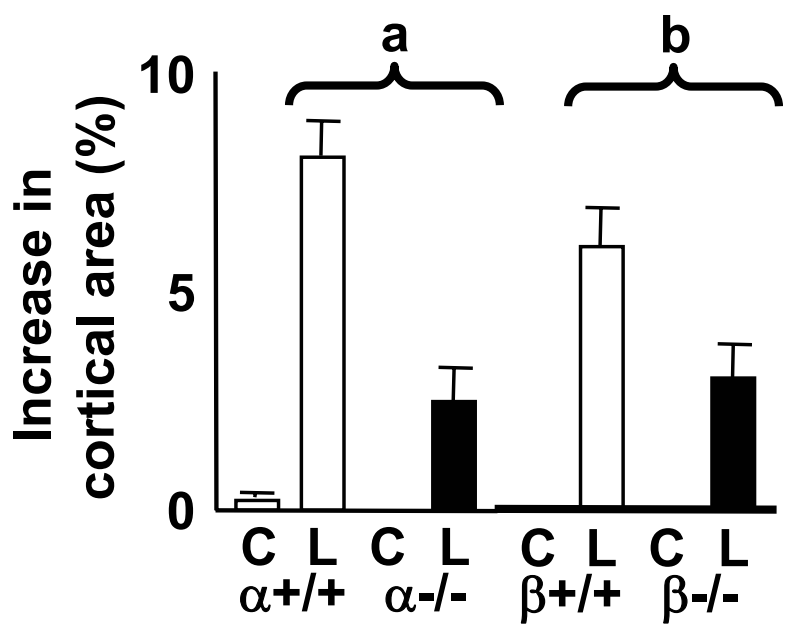

Figure 5 The loading-induced percentage increase in cortical area in $\mathrm{ER \alpha}^{+/+}(\alpha+/+), \mathrm{ER}^{-/-}(\alpha-/-), \mathrm{ER}^{+/+}(\beta+/+)$ and $\mathrm{ER} \beta^{-/-}$ $(\beta-/-)$ ulnae. $C$, control ulnae; $L$, loaded ulnae. $a, P<0 \cdot 001 ; b$, $P<0 \cdot 010$ for comparisons between knockout and wild-type littermates. Values are means \pm S.E.

The in vitro proliferative response to mechanical strain of osteoblast-like cells is absent in ERa ${ }^{-1-}$ cells, but enhanced in $E R \beta^{-1-}$ cells compared with wild-type cells

A 10-min period of mechanical strain resulted in a $61 \pm 25 \%$ increase in cell number in osteoblast-like cells derived from $\mathrm{ER} \alpha^{+/+}$mice $(P=0 \cdot 05)$ over the following $24 \mathrm{~h}$. The same treatment resulted in a $125 \pm 40 \%$ increase in cell number in osteoblast-like cells derived from $\mathrm{ER} \beta^{-/-}$mice $(P=0 \cdot 02)$. Conversely, osteoblast-like cells derived from $\mathrm{ER} \alpha^{-/-}$mice showed no such increase in proliferation in response to mechanical strain, but rather experienced a $24 \pm 9 \%$ decrease in cell number $(P=0 \cdot 01)$. However transfection of osteoblast-like cells derived from $\mathrm{ER} \alpha^{-/-}$mice with a functional wild-type ER $\alpha$ vector restored the proliferative response to mechanical strain, resulting in a mechanical strain-induced $48 \pm 8 \%$ increase in cell number $(P=0 \cdot 02)$. This restoration was associated with a transfection efficiency of $20 \pm 2 \%$.

\section{Discussion}

In vivo, the ulna of female mice lacking fully functional ER $\alpha$ but possessing functional ER $\beta$ have a threefold lower osteogenic response to mechanical loading than their wild-type littermates. This finding in $\mathrm{ER} \alpha^{-1-}$ mice is consistent with the demonstration in vitro that $\operatorname{ER} \alpha^{-/-}$ osteoblast-like cells fail to increase their number in response to mechanical strain, but that this response can be restored by transfection with functional human ER $\alpha$. These findings support the concept that ER $\alpha$ is required for at least those components of bone's early adaptive response to mechanical loading, which involves increase in the number of osteoblasts and the formation of new bone. 
Table 2 The effect of mechanical loading on cortical bone formation

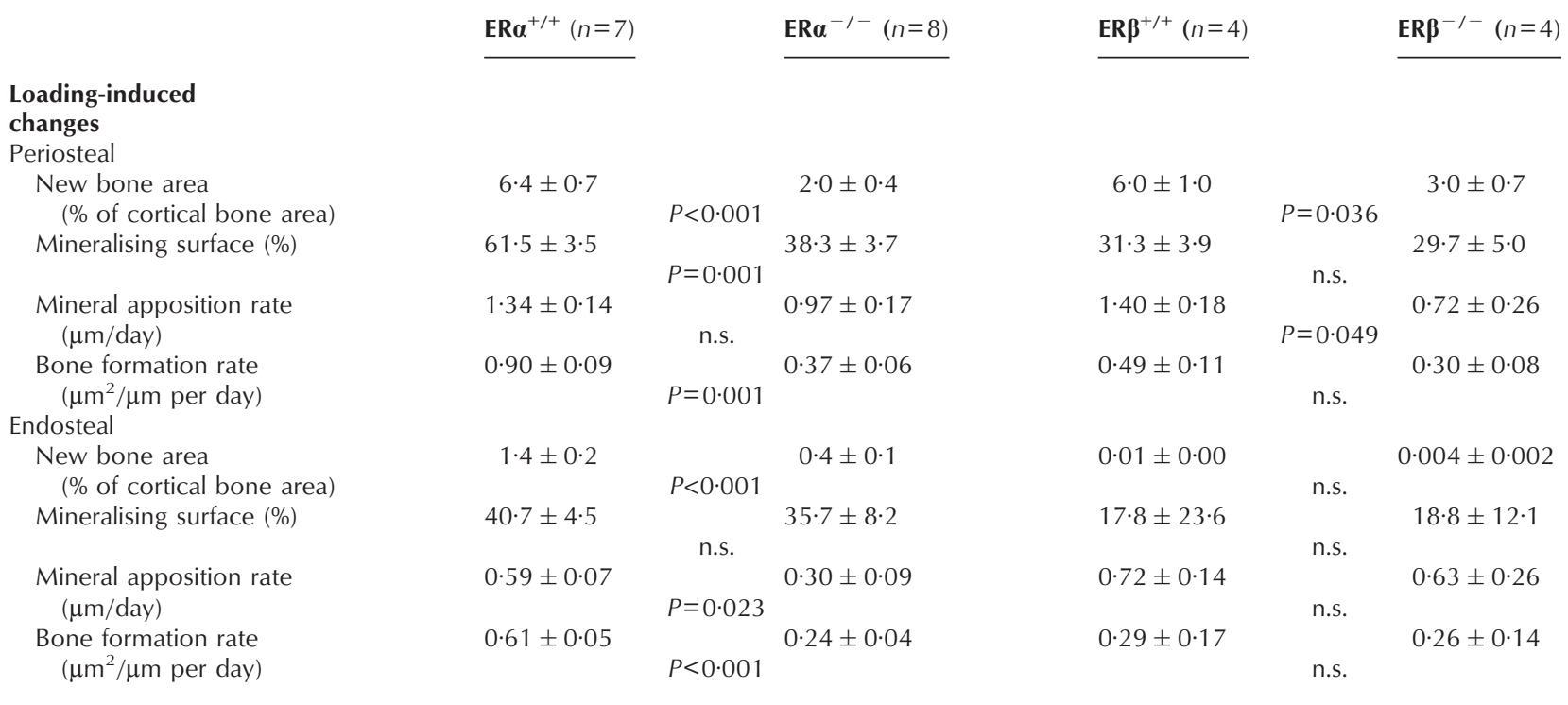

All parameters represent the loading-induced effect on bone formation $3.5 \mathrm{~mm}$ distal to the ulna midshaft and were calculated by subtracting the value for each control ulna from that of its paired loaded ulna.

$P$ values represent comparisons between knockouts $\left(E R \alpha^{-/-}\right.$and $\left.E R \beta^{-/-}\right)$and their wild-type littermates $\left(E R \alpha^{+/+}\right.$and $\left.E R \beta^{+/+}\right)$. n.s., $P>0 \cdot 05$.

Two ER $\alpha$ mRNA splice variants, which could result in the translation of a $55 \mathrm{kDa}$ protein and a $46 \mathrm{kDa}$ protein, have been detected in tissues from $\mathrm{ER} \alpha^{-/-}$mice (Couse et al. 1995, Pendaries et al. 2002, Shughrue et al. 2002). The $55 \mathrm{kDa}$ protein has not been detected in wild-type tissues and there is no evidence to suggest that it is capable of mimicking the actions of the full-length ER $\alpha$ protein in vivo (Couse et al. 1995, Pendaries et al. 2002). The $46 \mathrm{kDa} \mathrm{ER} \alpha$ isoform contains all the regions of the classical full-length ER $\alpha$ protein apart from the A/B domain (Pendaries et al. 2002). It has been shown to be capable of oestrogen-dependent ERE activation in vitro and in vivo and has been isolated from human primary osteoblasts (Metzger et al. 1995, Denger et al. 2001, Pendaries et al. 2002, Shughrue et al. 2002). The exact function of this protein in normal physiology has yet to be determined. Nonetheless, its possible presence does not detract from the findings of this study since it was clearly unable to fully compensate for the absence of the full-length ER $\alpha$ protein in this model of bone adaptation.

If $\mathrm{ER} \alpha$ is required for bone's adaptive response to mechanical loading, then the simple absence of functional ER $\alpha$ should lead to a disuse bone phenotype. In this study, the ulnae of adult female ER $\alpha^{-/}$mice were observed to be straighter than their wild-type counterparts. This is significant because mechanical loading is required for the development of a normal bone curvature (Chalmers \& Ray 1962, Lanyon 1980, Rodriguez et al. 1988). The absence of a normal ulnar curvature in $\operatorname{ER} \alpha^{-1-}$ mice is therefore consistent with an abnormal response to natural mechanical loading during growth. However, in other respects the structure of the $\operatorname{ER} \alpha^{-/-}$ulnae does not suggest a disuse phenotype: these bones are shorter in length, with a greater cortical thickness and similar structural stiffness to wild-type ulnae (Vidal et al. 1999, 2000, Lindberg et al. 2001).

The absence of an uncomplicated disuse phenotype and the presence of a small in vivo osteogenic response to mechanical loading in ER $\alpha^{-1-}$ mice may be due to a number of influences including high circulating oestrogen and testosterone concentrations (Couse \& Korach 1999, Kousteni et al. 2001, Lindberg et al. 2002, Sims et al. 2002), low insulin-like growth factor concentrations (Lindberg et al. 2001) and possible compensatory effects of unopposed ER $\beta$ (Sims et al. 2002).

The in vivo and in vitro data from the $\operatorname{ER} \beta^{-/-}$mice appear inconsistent with one another. In vivo, the ulna of female mice lacking fully functional ER $\beta$ but possessing functional $\operatorname{ER} \alpha$ have a twofold lower osteogenic response to mechanical loading than their wild-type littermates. Conversely, in vitro ER $\beta^{-/-}$osteoblast-like cells show a greater increase in cell number in response to mechanical strain compared with wild-type cells. The data presented in this study do not permit us to explain this apparent discrepancy.

The in vitro data suggested that ER $\beta$ decreases while $\mathrm{ER} \alpha$ enhances the strain-related increase in cell number in response to mechanical strain. This suggested that $\operatorname{ER} \beta$ 
either opposes the effects of ER $\alpha$ or suppresses the effects of $\mathrm{ER} \alpha$ with respect to the $\mathrm{ER} \alpha$-mediated strain-related increase in osteoblast cell number. Such antagonism between ER $\alpha$ and ER $\beta$ has been described in previous in vitro studies. One such study using a mouse osteoblast cell line found that an increase in ER $\beta$ expression resulted in a suppression of oestrogen-dependent ER $\alpha$-mediated activation of the AP1 transcriptional factor, c-fos (Ishibashi et al. 2001). Another study found that $E R \alpha$ and $E R \beta$ have opposite effects on AP1 transcription sites in breast cancer and uterine cell lines (Paech et al. 1997). However, the in vivo data suggested that the presence of $\operatorname{ER} \beta$ as well as ER $\alpha$ enhances bone's osteogenic response to mechanical loading.

In our present study it may be that $\operatorname{ER} \beta$ acts differently in the absence of ER $\alpha$ than in its presence (Sims et al. 2002). For example, their dual presence may result in the formation of heterodimers, which may have distinct actions compared with those of homodimers (Pettersson et al. 1997). However, this would not explain the difference in response between the in vitro and in vivo experiments presented, since the cells in the in vitro study were derived from the same population of mice as that used in the in vivo study. The ER $\beta^{-/-}$mouse used in this study is believed to be a true knockout and has not been shown to contain any mutant or non-mutant ER $\beta$ gene transcripts (Krege et al. 1998). Therefore the presence of such transcripts should not be involved in this response. However, secondary consequences of the absence of functional $\operatorname{ER} \beta$ protein in other tissues may affect the in vivo responses of bone to mechanical loading, but may not be evident in pure cultures of osteoblast-like cells. In addition, the formation of new bone during a 2-week period of loading in vivo is likely to be a much more complex process compared with the increase in number of osteoblast-like cells in the $24 \mathrm{~h}$ after strain in vitro.

We can conclude from the results of this study that functional ER number is an important determinant of the capacity of bone to adapt to mechanical loading in vivo. Changes in functional ER $\alpha$ number may help to explain the aetiology of the structurally inappropriate bone loss, which occurs at and after the menopause in women and is associated with low available oestrogen levels in men. Our data are somewhat equivocal on the role of ER $\beta$. The level of strain-related change in cell number in vitro suggested that $\operatorname{ER} \beta$ opposes the effect of ER $\alpha$. However, there was no evidence of any such inhibition being removed in vivo where the constitutive absence of either $\operatorname{ER} \alpha$ or $\operatorname{ER} \beta$ is associated with a smaller osteogenic response to loading than if both receptors were present.

\section{Acknowledgements}

We thank Professors Korach and Smithies for permission to use the $\mathrm{ER} \alpha^{-/-}$and $\mathrm{ER} \beta^{-/-}$mice.

\section{Funding}

This work was funded by The Wellcome Trust.

\section{References}

Ankrom MA, Patterson JA, d'Avis PY, Vetter UK, Blackman MR, Sponseller PD, Tayback M, Robey PG, Shapiro JR \& Fedarko NS 1998 Age-related changes in human oestrogen receptor alpha function and levels in osteoblasts. Biochemical Journal 333 787-794.

Chalmers J \& Ray RD 1962 The growth of transplanted foetal bones in different immunological environments. Journal of Bone and Joint Surgery 44B 149-164.

Cheng MZ, Rawlinson SC, Pitsillides AA, Zaman G, Mohan S, Baylink DJ \& Lanyon LE 2002 Human osteoblasts' proliferative responses to strain and 17 beta-estradiol are mediated by the estrogen receptor and the receptor for insulin-like growth factor I. Journal of Bone and Mineral Research 17 593-602.

Couse JF \& Korach KS 1999 Estrogen receptor null mice: what have we learned and where will they lead us? Endocrine Reviews 20 358-417.

Couse JF, Curtis SW, Washburn TF, Lindzey J, Golding TS, Lubahn DB, Smithies O \& Korach KS 1995 Analysis of transcription and estrogen insensitivity in the female mouse after targeted disruption of the estrogen receptor gene. Molecular Endocrinology 9 1441-1454.

Damien E, Price JS \& Lanyon LE 1998 The estrogen receptor's involvement in osteoblasts' adaptive response to mechanical strain. Journal of Bone and Mineral Research 13 1275-1282.

Damien E, Price JS \& Lanyon LE 2000 Mechanical strain stimulates osteoblast proliferation through the estrogen receptor in males as well as females. Journal of Bone and Mineral Research $\mathbf{1 5}$ 2169-2177.

Denger S, Reid G, Kos M, Flouriot G, Parsch D, Brand H, Korach KS, Sonntag-Buck V \& Gannon F 2001 ERalpha gene expression in human primary osteoblasts: evidence for the expression of two receptor proteins. Molecular Endocrinology 15 2064-2077.

Hoyland JA, Baris C, Wood L, Baird P, Selby PL, Freemont AJ \& Braidman IP 1999 Effect of ovarian steroid deficiency on oestrogen receptor alpha expression in bone. Journal of Pathology 188 294-303.

Ishibashi O, Yamagishi T, Hanada K \& Kawashima H 2001 Tamoxifen agonism and estrogen antagonism of c-fos gene promoter activity through non-consensus-responsive elements in MC3T3-E1 osteoblasts. Biochemical and Biophysical Research Communications 289 705-711.

Jessop HL, Sjoberg M, Cheng MZ, Zaman G, Wheeler-Jones CP \& Lanyon LE 2001 Mechanical strain and estrogen activate estrogen receptor alpha in bone cells. Journal of Bone and Mineral Research 16 1045-1055.

Jessop HL, Rawlinson SC, Pitsillides AA \& Lanyon LE 2002 Mechanical strain and fluid movement both activate extracellular regulated kinase (ERK) in osteoblast-like cells but via different signaling pathways. Bone 31 186-194.

Kos M, Reid G, Denger S \& Gannon F 2001 Minireview: genomic organization of the human ERalpha gene promoter region. Molecular Endocrinology 15 2057-2063.

Kos M, Denger S, Reid G \& Gannon F 2002 Upstream open reading frames regulate the translation of the multiple mRNA variants of the estrogen receptor alpha. Journal of Biological Chemistry 277 37131-37138.

Kousteni S, Bellido T, Plotkin LI, O'Brien CA, Bodenner DL, Han L, Han K, DiGregorio GB, Katzenellenbogen JA, Katzenellenbogen BS, Roberson PK, Weinstein RS, Jilka RL \& Manolagas SC 2001 Nongenotropic, sex-nonspecific signaling through the estrogen or androgen receptors: dissociation from transcriptional activity. Cell 104 719-730. 
Krege JH, Hodgin JB, Couse JF, Enmark E, Warner M, Mahler JF, Sar M, Korach KS, Gustafsson JA \& Smithies O 1998 Generation and reproductive phenotypes of mice lacking estrogen receptor beta. PNAS 95 15677-15682.

Lanyon LE 1980 The influence of function on the development of bone curvature. An experimental study on the rat tibia. Journal of the Zoological Society of London 192 457-466.

Lanyon L \& Skerry T 2001 Postmenopausal osteoporosis as a failure of bone's adaptation to functional loading: a hypothesis. Journal of Bone and Mineral Research 16 1937-1947.

Lee KC, Maxwell A \& Lanyon LE 2002 Validation of a technique for studying functional adaptation of the mouse ulna in response to mechanical loading. Bone 31 407-412.

Lee K, Jessop H, Suswillo R, Zaman G \& Lanyon L 2003 Bone adaptation requires oestrogen receptor-alpha. Nature 424389.

Lim SK, Won YJ, Lee HC, Huh KB \& Park YS 1999 A PCR analysis of ERalpha and ERbeta mRNA abundance in rats and the effect of ovariectomy. Journal of Bone and Mineral Research $\mathbf{1 4}$ 1189-1196.

Lindberg MK, Alatalo SL, Halleen JM, Mohan S, Gustafsson JA \& Ohlsson C 2001 Estrogen receptor specificity in the regulation of the skeleton in female mice. Journal of Endocrinology 171 229-236.

Lindberg MK, Weihua Z, Andersson N, Moverare S, Gao H, Vidal O, Erlandsson M, Windahl S, Andersson G, Lubahn DB, Carlsten H, Dahlman-Wright K, Gustafsson JA \& Ohlsson C 2002 Estrogen receptor specificity for the effects of estrogen in ovariectomized mice. Journal of Endocrinology 174 167-178.

Lubahn DB, Moyer JS, Golding TS, Couse JF, Korach KS \& Smithies O 1993 Alteration of reproductive function but not prenatal sexual development after insertional disruption of the mouse estrogen receptor gene. PNAS 90 11162-11166.

Metzger D, Ali S, Bornert JM \& Chambon P 1995 Characterization of the amino-terminal transcriptional activation function of the human estrogen receptor in animal and yeast cells. Journal of Biological Chemistry 270 9535-9542.

Mosley JR, March BM, Lynch J \& Lanyon LE 1997 Strain magnitude related changes in whole bone architecture in growing rats. Bone $\mathbf{2 0}$ 191-198.

Paech K, Webb P, Kuiper GG, Nilsson S, Gustafsson J, Kushner PJ \& Scanlan TS 1997 Differential ligand activation of estrogen receptors ERalpha and ERbeta at AP1 sites. Science 277 1508-1510.

Parfitt AM, Drezner MK, Glorieux FH, Kanis JA, Malluche H, Meunier PJ, Ott SM \& Recker RR 1987 Bone histomorphometry: standardization of nomenclature, symbols, and units. Report of the ASBMR Histomorphometry Nomenclature Committee. Journal of Bone and Mineral Research 2 595-610.

Pendaries C, Darblade B, Rochaix P, Krust A, Chambon P, Korach KS, Bayard F \& Arnal JF 2002 The AF-1 activation-function of ERalpha may be dispensable to mediate the effect of estradiol on endothelial NO production in mice. PNAS 99 2205-2210.

Pettersson K, Grandien K, Kuiper GG \& Gustafsson JA 1997 Mouse estrogen receptor beta forms estrogen response element binding heterodimers with estrogen receptor alpha. Molecular Endocrinology 11 1486-1496.

Rago R, Mitchen J \& Wilding G 1990 DNA fluorometric assay in 96-well tissue culture plates using Hoechst 33258 after cell lysis by freezing in distilled water. Analytical Biochemistry 191 $31-34$.
Riggs BL, Khosla S \& Melton LJ III 2002 Sex steroids and the construction and conservation of the adult skeleton. Endocrine Reviews 23 279-302.

Rodriguez JI, Palacios J, Garcia-Alix A, Pastor I \& Paniagua R 1988 Effects of immobilization on fetal bone development. A morphometric study in newborns with congenital neuromuscular diseases with intrauterine onset. Calcified Tissue International $\mathbf{4 3}$ 335-339.

Sheng MH, Baylink DJ, Beamer WG, Donahue LR, Rosen CJ, Lau KH \& Wergedal JE 1999 Histomorphometric studies show that bone formation and bone mineral apposition rates are greater in $\mathrm{C} 3 \mathrm{H} / \mathrm{HeJ}$ (high-density) than C57BL/6J (low-density) mice during growth. Bone 25 421-429.

Shughrue PJ, Askew GR, Dellovade TL \& Merchenthaler I 2002 Estrogen-binding sites and their functional capacity in estrogen receptor double knockout mouse brain. Endocrinology 143 $1643-1650$

Sims NA, Dupont S, Krust A, Clement-Lacroix P, Minet D, Resche-Rigon M, Gaillard-Kelly M \& Baron R 2002 Deletion of estrogen receptors reveals a regulatory role for estrogen receptors-beta in bone remodeling in females but not in males. Bone 30 18-25.

Srinivasan S, Weimer DA, Agans SC, Bain SD \& Gross TS 2002 Low-magnitude mechanical loading becomes osteogenic when rest is inserted between each load cycle. Journal of Bone and Mineral Research 17 1613-1620.

Tzukerman MT, Esty A, Santiso-Mere D, Danielian P, Parker MG, Stein RB, Pike JW \& McDonnell DP 1994 Human estrogen receptor transcriptional capacity is determined by both cellular and promoter context and mediated by two functionally distinct intramolecular regions. Molecular Endocrinology $\mathbf{8}$ 21-30.

Vidal O, Lindberg M, Savendahl L, Lubahn DB, Ritzen EM, Gustafsson JA \& Ohlsson C 1999 Disproportional body growth in female estrogen receptor-alpha-inactivated mice. Biochemical and Biophysical Research Communications 265 569-571.

Vidal O, Lindberg MK, Hollberg K, Baylink DJ, Andersson G, Lubahn DB, Mohan S, Gustafsson JA \& Ohlsson C 2000 Estrogen receptor specificity in the regulation of skeletal growth and maturation in male mice. PNAS 97 5474-5479.

Windahl SH, Vidal O, Andersson G, Gustafsson JA \& Ohlsson C 1999 Increased cortical bone mineral content but unchanged trabecular bone mineral density in female ERbeta $\left(^{-1-}\right)$ mice. Journal of Clinical Investigation 104 895-901.

Windahl SH, Hollberg K, Vidal O, Gustafsson JA, Ohlsson C \& Andersson G 2001 Female estrogen receptor beta $^{-/-}$mice are partially protected against age-related trabecular bone loss. Journal of Bone and Mineral Research 16 1388-1398.

Zaman G, Suswillo RF, Cheng MZ, Tavares IA \& Lanyon LE 1997 Early responses to dynamic strain change and prostaglandins in bone-derived cells in culture. Journal of Bone and Mineral Research 12 769-777.

Zaman G, Cheng MZ, Jessop HL, White R \& Lanyon LE 2000 Mechanical strain activates estrogen response elements in bone cells. Bone 27 233-239.

Received 18 May 2004

Accepted 28 May 2004 